\title{
Copepod egg production during highly productive late spring conditions: importance of freshly ingested food and lipid storage
}

\author{
Sara Ceballos*, Leticia Viesca, Florentina Álvarez-Marqués \\ Universidad de Oviedo, Departamento de Biología de Organismos y Sistemas, Campus del Cristo, \\ Catedrático Rodrigo Uría s/n, CP-33071 Oviedo, Spain
}

\begin{abstract}
The reproductive activity of 2 calanoid copepods, Calanus helgolandicus and Calanoides carinatus, under post-bloom conditions was investigated during a cruise in the central Cantabrian Sea (SW Bay of Biscay) in May 2000. Several mesoscale structures, such as an upwelling of rich waters associated with the topography of one submarine canyon, were observed on the continental shelf. Consequently, a high biomass of large phytoplankton was found in coastal and mid-shelf areas. These unexpected productive conditions after the spring bloom supplied copepods with favourable food resources. Accordingly, females showed mature gonads, high percentages of spawning and high egg production rates (EPRs). A surface saline current was detected flowing parallel to the coast along the slope. A microbial food web prevailed there and, unlike the coast and mid-shelf areas, low chlorophyll concentrations and a high proportion of small phytoplankton were found. The microbial food web did not seem to be suitable to support copepod production; thus, only a few females had mature gonads and fecundity was low. The number of eggs produced increased as herbivorous feeding increased, but feeding on phytoplankton did not cover the carbon requirements at all stations, and a mixed diet was suggested. The relationship between EPR and diatom concentration showed a saturation response for both species, but interestingly the saturation concentration was low and fecundity values were sub-maximal. Females had low lipid levels and low C:N ratios, indicating that egg production could be entirely fuelled by freshly ingested food. The low lipid reserves of females could also help to explain the sub-maximal EPR of $C$. helgolandicus. Nevertheless, low lipid storage was not a constraint for $C$. carinatus because it is well known that this species uses only freshly ingested food to support egg production. The implications of this extra productive time at the end of spring on the annual recruitment of C. helgolandicus and C. carinatus are discussed.
\end{abstract}

KEY WORDS: Copepods - Egg production $\cdot$ Lipid storage $\cdot$ Herbivorous feeding $\cdot$ Late spring · Calanus helgolandicus $\cdot$ Calanoides carinatus $\cdot$ SW Bay of Biscay

\section{INTRODUCTION}

The link between the spring phytoplankton bloom and the bulk of copepod productivity is widely recognized (e.g. Runge 1988, Cushing 1989). Because of the lower growth rate of herbivorous copepods compared to phytoplankton, a time lag between the production peaks of the primary producers and their consumers is usually observed in temperate waters. During the late phase of the spring bloom, the phytoplankton commu- nity is normally dominated by large cells, and mesozooplankton have already developed a high biomass in response to the abundant food resources supplied by the active phytoplankton growth. According to the trophic pathway classification proposed by Legendre \& Rassoulzadegan (1996), this situation corresponds to a herbivorous food web, where mesozooplankton exert strong grazing pressure on large phytoplankton.

A long time-series study in the central Cantabrian Sea (SW Bay of Biscay) shows an uncoupling between 
spring peaks of phytoplankton and mesozooplankton biomass (M. Llope et al. unpubl. data). Phytoplankton typically develops its highest biomass and production level between March and April, coinciding with the transition from mixed to stratified water conditions (Fernández \& Bode 1991), whereas the highest mesozooplankton biomass occurs in May under post-bloom conditions. Nevertheless, this seasonal pattern may be modulated by some shelf-related mesoscale processes that occur during the late spring in the central Cantabrian Sea. In May 1996, González-Quirós et al. (2003) observed an additional input of nutrients into the euphotic layer due to a dome-shaped density feature associated with the shelf break front and with the topography of the Avilés submarine canyon. The phytoplankton community responded with high values of biomass and production, which were very similar to those of the previous spring phytoplankton bloom. A comprehensive survey (Sardina cruise) was conducted in May 2000 to describe shelf-related mesoscale structures and their effects on primary production, food web structure and the fish larvae retention process (González-Quirós et at. 2004). The hydrodynamics were characterised by a slope saline current, in which the microbial food web prevailed, and a dome-shaped nutrient feature as well as an upwelling of deep water associated with the topography of the Avilés canyon; both of the last 2 features induced a high productivity of large phytoplankton in mid-shelf and coastal waters. Under these conditions, an increase in the energy flow towards higher trophic levels is expected at the continental shelf. The high biomass of mesozooplankton detected in nearshore waters would support this idea (González-Quirós et al. 2004). These conditions also suggest an additional opportunity for recruitment at the end of spring for herbivorous copepods that reproduce seasonally. Given that they reach their maximum abundance at this time of the year, this would result in an important increase in their annual productivity.

In the present work, we studied the ability of 2 herbivorous calanoid copepods, Calanus helgolandicus and Calanoides carinatus, to exploit these post-bloom spring conditions. We measured their reproductive activity during a cruise in the central Cantabrian Sea. Our hypothesis is that these 2 species take full advantage of the favorable food conditions promoted by the shelf-related mesoscale structures, so high reproductive activity is expected in the shelf and coastal areas.

Calanoides carinatus inhabits all upwelling areas around the Africa continent (see Verheye et al. 1991 and references therein). Its reproduction is strongly coupled to the high food availability (mainly diatoms) induced by the upwelling events (e.g. Smith 2001). C. carinatus is also found in the Bay of Biscay (e.g. John et al. 1998), but its biology remains fairly unknown in this area. A recent study of its reproductive response to an upwelling event off NW Spain suggested a reproductive strategy less dependent on upwelling episodes (Ceballos et al. 2004). Moreover, our previous observations in the central Cantabrian Sea show that C. carinatus and Calanus helgolandicus attain highest abundances during spring, when their main reproductive output also occurs (Ceballos \& Álvarez-Marqués 2006). In situ production of C. helgolandicus in areas near the Cantabrian Sea also showed a strong link between recruitment events and periods of phytoplankton productivity, for example, the phytoplankton spring bloom in the English Channel (Pond et al. 1996, Laabir et al. 1998), and the summer upwelling off the NW coast of Spain (Ceballos et al. 2004). These species are very representative of the copepod community in the Bay of Biscay ( $C$. helgolandicus), or in the Cantabrian Sea (both species), because they rank among the 10 most abundant and frequently occurring species (ÁlvarezMarqués 1982, Poulet et al. 1996). Both species attained high abundances during spring and are the most frequent and abundant Calanidae thoughout the year (Álvarez- Marqués 1982, 1984)

In addition to freshly ingested food, Calanus spp. can also use internal energy stores to fuel reproduction, although their role is complex. It is normally accepted that Vitellogenesis I occurs in Stage V copepodites and that it is fuelled by lipid reserves, whereas Vitellogenesis II and final maturation of the ova in young females depend on freshly ingested food. However, some populations of $C$. finmarchicus can produce eggs before the spring bloom, apparently using only stored lipids (e.g. Richardson et al. 1999), and Niehoff et al. (2002) reported that $C$. hyperboreus egg production is independent of food supply. As for $C$. helgolandicus, recent laboratory studies (Rey-Rassat et al. 2002b) suggest that egg production over the entire lifespan does not rely solely on immediate carbon intake, but also on a buffer of lipid reserves, which reflect past feeding conditions and the developmental condition of the females. Likewise, Calanoides carinatus has large lipid reserves that also play an important role in reproduction, although unlike $C$. helgolandicus, lipids do not seem to be directly involved in its reproductive activity. Armstrong et al. (1991) showed that these lipid reserves are used to enhance the survival of $C$. carinatus females in the southern Benguela Current when food is scarce, such as during the non-upwelling season or between upwelling pulses. This strategy ensures a rapid response of females to subsequent high food supply. Because of this, our secondary goal was to measure the herbivorous feeding rate and lipid storage of females in order to examine the influence of both factors on the in situ egg production rates recorded during our cruise. 


\section{MATERIALS AND METHODS}

Sampling procedures. Data were collected in the central Cantabrian Sea (SW Bay of Biscay) during the Sardina cruise on board the RV 'García del Cid', from 2 to 17 May 2000. A total of 11 stations were sampled during the daytime (09:00 to 13:00 h) along 4 transects perpendicular to the coast (Fig. 1). Vertical profiles of temperature, salinity and fluorescence were taken at each station using a Mark III CTD with a Sea-Tech fluorometer attached to a rosette of 24 Teflon Niskin bottles. Live experimental animals were collected with a triple WP2 net $(0.60 \mathrm{~m}$ diameter, $200 \mu \mathrm{m}$ mesh) equipped with 31 cod-ends. Hauls were made vertically from $200 \mathrm{~m}$ to the surface, or from $5 \mathrm{~m}$ above the bottom to the surface at the coastal stations. Once on deck, 1 or 2 cod-ends were immediately processed for gut pigment content analysis. Another haul was made and the 3 cod-ends were diluted in a 51 plastic jar filled with $100 \mu \mathrm{m}$-filtered seawater to ensure that the animals remained alive for our experiments. Water used for the incubations was collected with Van Dorn bottles (15 l) from the depth of maximum fluorescence (MFD). Bongo net hauls were performed to collect zooplankton samples for abundance estimations as described in González-Quirós et al. (2004). A bongo net $(0.60 \mathrm{~m}$ diameter, $200 \mu \mathrm{m}$ mesh) equipped with calibrated flowmeters was towed obliquely from $200 \mathrm{~m}$ to the surface, or from $5 \mathrm{~m}$ above the bottom to the surface at coastal stations. Samples were preserved in $4 \%$ buffered formaldehyde.

Food availability. Chlorophyll a (chl a) concentration and microplankton composition were used as indicators of potential copepod food availability. $\mathrm{Chl}$ a concentration was determined as described in González-Quirós et al. (2004). Briefly, water samples of $100 \mathrm{ml}$ were collected from depths with 100 and $1 \%$ of incident light, and from the MFD; depending on the station depth, 1 or 2 additional samples were taken at increasing intervals. Samples were filtered sequentially through 5 and $0.2 \mu \mathrm{m}$ polycarbonate filters because it has been suggested that $5 \mu \mathrm{m}$ is the size above which copepods graze efficiently (e.g. Cushing 1989). Pigments were extracted in $5 \mathrm{ml}$ of $95 \%$ acetone at $4{ }^{\circ} \mathrm{C}$ overnight and the chl a concentration was measured fluorometrically before and after acidification $(1 \mathrm{~N} \mathrm{HCl})$ using a Turner Design Model 10 fluorometer. Total chl a was calculated as the sum of the 2 size fractions ( 0.2 to $5 \mu \mathrm{m}$ and $>5 \mu \mathrm{m})$. Chl a concentration was integrated in the water column. For most stations the integration depth was $100 \mathrm{~m}$, but for the coastal stations (Stns A1, A2, B1 and C1) the integration depth was 23, 65,40 and $40 \mathrm{~m}$, respectively. The maximum value of chl a ( $\left.\mathrm{chl} a_{\max }\right)$ was also used to describe the food environment of the copepods.
For microplankton composition and abundance, $125 \mathrm{ml}$ water samples were taken at 3 depths within the euphotic zone (100 and 1\% of light incidence and the MFD). Samples were preserved with Lugol's solution (3\% final concentration) and concentrated by gravimetric sedimentation in Utermöhl chambers $(25 \mathrm{ml})$. When possible, cells $>5 \mu \mathrm{m}$ were identified to the species level using an inverted microscope. Microplankton cell abundance was transformed into carbon units. Cells were measured using a digital analysis system. The carbon content was estimated from cell volume by approximation to the nearest geometric shape (Hillebrand et al. 1999) and by applying the carbon conversion factors proposed by Putt \& Stoecker (1989) for ciliates, and by Menden-Deuer \& Lessard (2000) for the remaining groups. The abundances were integrated in the euphotic zone (cells $\mathrm{m}^{-2}$, $\mathrm{mg} \mathrm{C} \mathrm{m}{ }^{-2}$ ). The euphotic depth varied from 40 to $60 \mathrm{~m}$, but it was shallower at the coastal stations (Stns A1 and A2), where it was 23 and $28 \mathrm{~m}$, respectively. The mean abundance for the euphotic zone was also calculated (cells ml ${ }^{-1}$ ).

Biomass, prosome length, gonad development and oil sac volume of females. Measurements of body carbon $(\mathrm{C})$ and nitrogen $(\mathrm{N})$ content of females were made on 3 replicates of 4 individuals at each station. Live

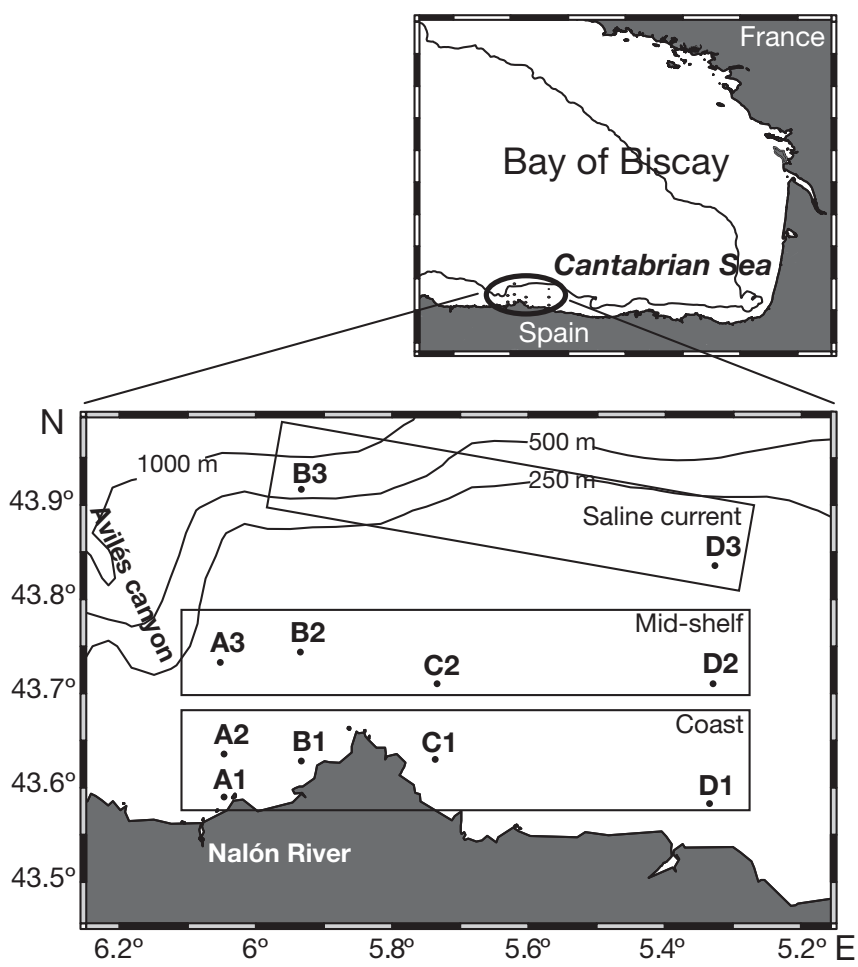

Fig. 1. Map showing study area. Stations were grouped into coastal (<100 m depth), mid-shelf (100 to $200 \mathrm{~m}$ depth) and slope saline current stations 
females were picked under a dissecting microscope, rinsed in distilled water to remove adhering material, and transferred to pre-combusted GF/A filters. Excess water was removed by filtering with low vacuum pressure, and then the filters were frozen $\left(-20^{\circ} \mathrm{C}\right)$. In the laboratory, the filters were dried at $60^{\circ} \mathrm{C}$ for $48 \mathrm{~h}$ before estimating $\mathrm{C}$ and $\mathrm{N}$ content with a Perkin Elmer 2400 Elemental Analyzer. The prosome length of 40 preserved females for each station was measured in lateral view using a video image analysing system. This system was also used to measure the oil sac volume (estimated as an ellipse volume; Plourde \& Runge 1993) of preserved females from each station. The volume was converted into wax ester (WE) content following Rey-Rassat et al. (2002b). In order to normalize the effect of female size, WE content was divided by prosome volume, which was estimated following Mauchline (1998).

Gonad development of females was also used to describe the reproductive status of the Calanus helgolandicus and Calanoides carinatus populations. The females used to measure the prosome length were stained and classified into 6 gonad development stages following Ceballos et al. (2004). The reproductive index (RI) was calculated as the proportion of females with mature gonads and therefore ready to spawn in $24 \mathrm{~h}$ incubations (e.g. Runge \& Roff 2000).

Egg production experiments. Between 10 and 15 healthy and fertilised females (i.e. with full spermatheca) of Calanus helgolandicus and Calanoides carinatus were gently sorted, under a dissecting microscope, and placed individually in Nalgene, bottles containing $200 \mathrm{ml}$ of $100 \mu \mathrm{m}$-filtered seawater from the MFD. Experiments were run by maintaining the bottles in a deck incubator equipped with a temperature control system $\left( \pm 0.1^{\circ} \mathrm{C}\right)$ at the temperature of the MFD $\left(12.7\right.$ to $\left.13.6^{\circ} \mathrm{C}\right)$. This was done under dim light with a natural photoperiod brought about by covering the container during the dark hours to avoid the influence of the ship's lights. The bottles were gently shaken 2 to 3 times per day to avoid cells settling. At the end of incubation $(24 \mathrm{~h})$, the viability of the females was checked and the eggs were filtered onto a $33 \mu \mathrm{m}$ mesh and preserved at $-20^{\circ} \mathrm{C}$ in vials, until being counted in the laboratory. Egg production rates (EPR) were calculated as the number of egg spawned per female per day. Only live females were considered in this calculation, although mortality was insignificant. The percentage of females that spawned during the incubation and the mean clutch size (CS) including only the bottles where females produced eggs were also calculated; it was assumed that females produced only 1 clutch during the incubation. Egg cannibalism was accounted for by including crumpled egg membranes in egg production counts (e.g. Ianora et al. 1995, Runge \& Roff 2000), but cannibalism was negligible.
The population EPR (eggs $\mathrm{m}^{-3} \mathrm{~d}^{-1}$ ) was calculated as the product of the EPR and female abundance, and could be considered as a gross estimation of the potential recruitment of Calanus helgolandicus and Calanoides carinatus. The population EPR was also converted into carbon units (mg C m $\mathrm{m}^{-3} \mathrm{~d}^{-1}$ ) by multiplying by the egg carbon content, which was estimated using a carbon/volume relationship of $0.14 \times 10^{-6} \mu \mathrm{g} \mathrm{C} \mu \mathrm{m}^{-3}$ assuming that eggs are spherical (Kiørboe et al. 1985). At each station a number of eggs were measured with an ocular micrometer attached to a microscope at $\times 10$ magnification. To determine $C$. carinatus egg diameter, the perivitelline space was not considered. No significant differences in egg size were found between stations for either species $\left(F_{9,352}=1.90, \mathrm{p}>0.05\right.$ for $C$. helgolandicus and $F_{9,390}=1.54, \mathrm{p}>0.05$ for $C$. carinatus); the mean values of egg diameter were $165.82 \mu \mathrm{m}$ $(0.33 \mu \mathrm{g} \mathrm{C})$ and $135.65 \mu \mathrm{m}(0.18 \mu \mathrm{g} \mathrm{C})$ for C. helgolandicus and C. carinatus, respectively.

Herbivorous feeding. Daily ingestion rates $(I)$ of phytoplankton by Calanus helgolandicus and Calanoides carinatus females were estimated from the gut fluorescence method (Mackas \& Bohrer 1976) using:

$$
I=G F \times K
$$

where $G F$ is the gut fluorescence and $K$ is the gut clearance rate, which was calculated following the equation shown in Båmstedt et al. (2000):

$$
K=0.0124 \times \mathrm{e}^{(0.07675 \times T)}\left(\mathrm{min}^{-1}\right)
$$

where $T$ is in situ temperature (mean column temperature here). $K$ values ranged between 0.033 and $0.037 \mathrm{~min}^{-1}$.

The content of 1 cod-end of the WP2 net was immediately filtered through an Albet $^{\circledR}$ filter paper $(47 \mathrm{~mm}$ diameter) on a low vacuum; the disc was wrapped in aluminium foil and frozen at $-20^{\circ} \mathrm{C}$. The entire process lasted $<3$ min. Samples were analysed 1 mo after they were frozen (Morales et al. 1993). For chlorophyll pigment extraction, 3 to 4 replicates of 10 to 15 females were quickly picked from frozen samples using a dissecting microscope under dim light, and placed in $90 \%$ acetone for 1 night in darkness at $4{ }^{\circ} \mathrm{C}$. Extracts were analysed with a Turner Design Model 10 fluorometer before and after acidification $(1 \mathrm{~N} \mathrm{HCl})$. Ingestion rates could be interpreted as conservative since our sampling was conducted during the daytime and both species usually have highest feeding activity during dark hours (Calanus helgolandicus: Harris \& Malej 1986; Calanoides carinatus: Timonin et al. 1992).

Ingested chl a was converted into carbon units using a C:chl a ratio of 156.13 , which is the slope of the linear regression between a chl a concentration of $>5 \mu \mathrm{m}$ and the carbon concentration of photosynthetic cells $(\mathrm{C}=$ 
$156.13 \mathrm{chl} a+8.80, \mathrm{R}^{2}=0.75, F_{1,33}=99.19 \mathrm{p}<0.001$, $\mathrm{N}=34$ ). The linear regression equation was calculated using all the sampled depths for microplankton composition (i.e. MFD, 100 and $1 \%$ of incident light) at all stations.

Statistical analysis. To test for differences between means 1-way ANOVAs and $t$-tests were applied. Kolmogorov-Smirnov and Bartlett tests were first performed to check for normality and homogeneity of variance. The differences in female carbon content between stations were examined using the Kruskal-Wallis test due to lack of data normality. Lipid data were log-transformed to achieve normality. When ANOVA results were significant $(\mathrm{p}<0.05)$, post-hoc comparisons were performed with the Tukey Honestly Significant Difference (HSD) test. The relationships between variables were explored using linear regression analyses and the Ivlev function: $Y=Y_{\max }\left(1-\mathrm{e}^{(-\alpha X)}\right)$.

This function represents a type II numerical/functional response (Dam et al. 1994), where $Y_{\max }$ is the corresponding maximum value of the rate (e.g. EPR or phytoplankton ingestion rate) and $X$ and $\alpha$ are the food concentration and the rate at which the biological rate attains the maximum value, respectively.

\section{RESULTS}

\section{Hydrology}

The summer thermal stratification was starting to develop at the time of sampling. Well-mixed water was restricted to the upper 10 to $20 \mathrm{~m}$; a weak thermocline was observed and a subsurface fluorescence maximum was detected (Fig. 2). Surface temperatures ranged from 13.2 to $15.4^{\circ} \mathrm{C}$, with highest temperatures along Transect A (Table 1). Surface salinity showed a coastal-oceanic gradient, with lowest salinities at the coastal stations of Transect A due to the fresh water runoff from the Nalón River (Fig. 1, Table 1).

Several mesoscale structures were encountered during the Sardina cruise (for detailed descriptions of these structures and of the biological effects of the hydrodynamics see González-Quirós et al. 2004). Firstly, a saline current (>35.64) was detected flowing along the slope. Two stations, Stns B3 and D3, were located inside the saline current (Fig. 1). Offshore and over the slope a surface meandering circulation was found. The inferred quasigeostrophic (QG) velocities
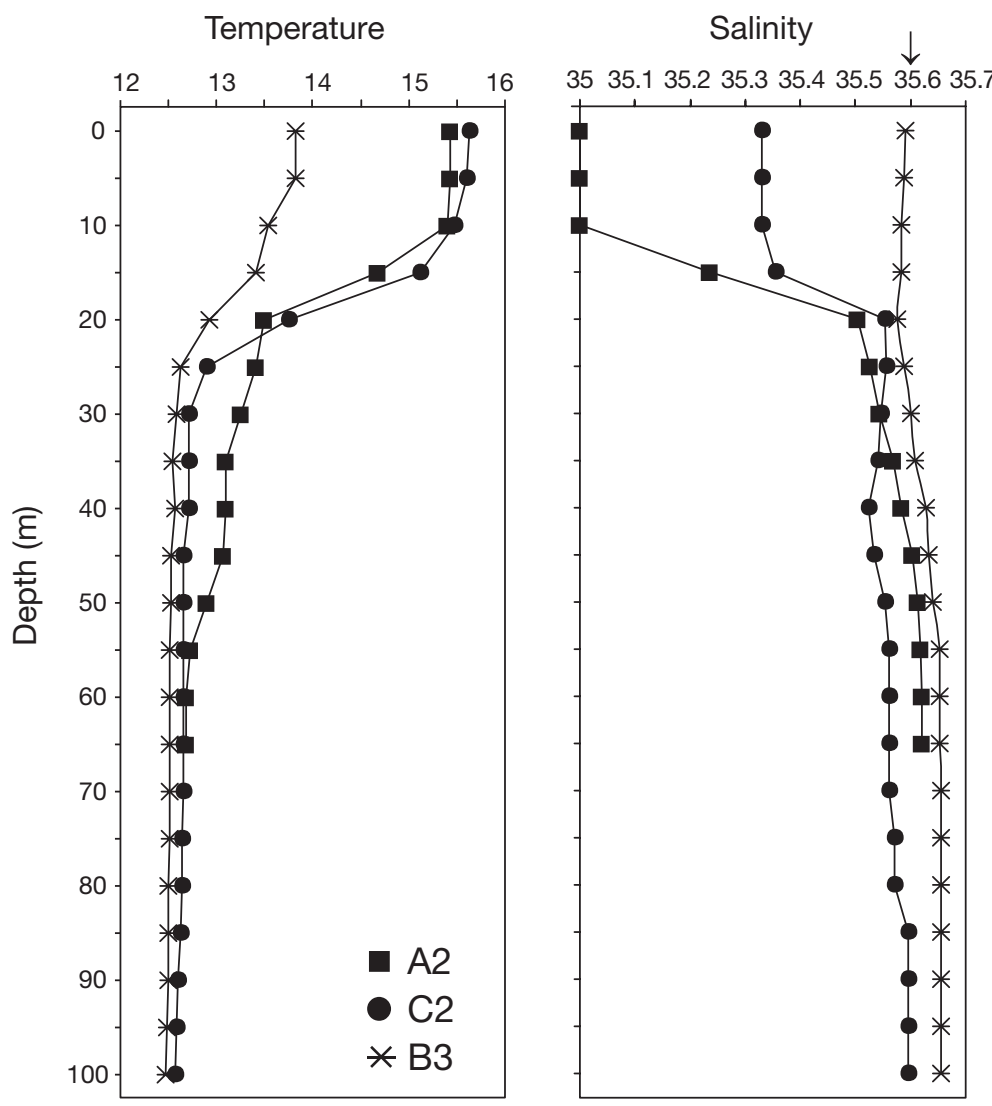

Fluorescence

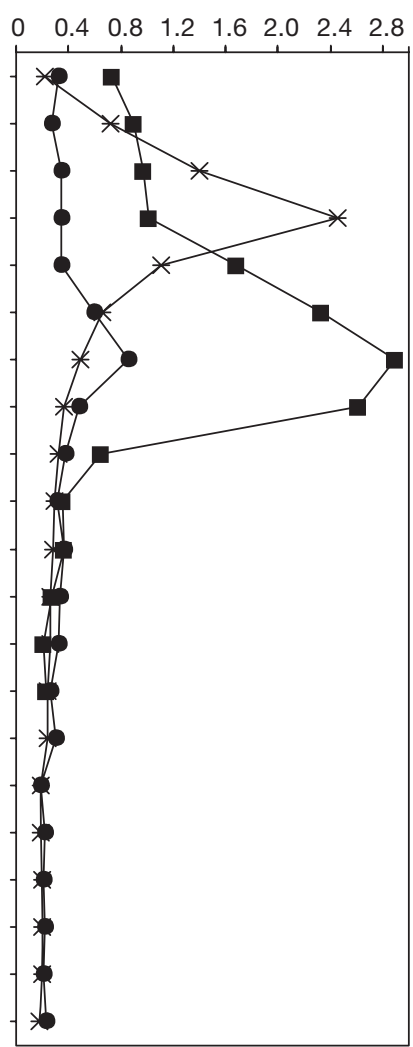

Fig. 2. Vertical profiles of temperature $\left({ }^{\circ} \mathrm{C}\right.$ ), salinity (arrow: salinity of the slope salinity current) and fluorescence (arbitrary units) at 3 selected stations that represent coastal (Stn A2), mid-shelf (Stn C2) and slope (Stn B3) conditions 
Table 1. Environmental variables in the study area. Surface and mean water column temperature $\left({ }^{\circ} \mathrm{C}\right)$, surface salinity and total and size-fractioned chlorophyll $a(\mathrm{chl} a)$. Chl $a$ is represented as the integrated $\left(\mathrm{mg} \mathrm{m}^{-2}\right)$, maximum and mean values in the water column $\left(\mu \mathrm{g} \mathrm{l}^{-1}\right)$. C: coast, MS: mid-shelf, SC: slope current, Max.: maximum value. See 'Materials and methods' for integration depth data

\begin{tabular}{|c|c|c|c|c|c|c|c|c|c|c|c|}
\hline \multirow[t]{3}{*}{ Transect } & \multirow[t]{3}{*}{ Zone } & \multirow[t]{3}{*}{ Stn } & \multicolumn{2}{|c|}{ Temperature } & \multirow[t]{3}{*}{ Salinity } & \multicolumn{6}{|c|}{$\mathrm{Chl} \mathrm{a}$} \\
\hline & & & \multirow[t]{2}{*}{ Surface } & \multirow{2}{*}{$\begin{array}{l}\text { Water } \\
\text { column }\end{array}$} & & \multicolumn{2}{|c|}{ Integrated } & \multirow{2}{*}{$\begin{array}{l}\text { Max. } \\
>5 \mu \mathrm{m}\end{array}$} & \multirow{2}{*}{$\begin{array}{l}\text { Max. } \\
\text { total }\end{array}$} & \multirow{2}{*}{$\begin{array}{c}\text { Mean } \\
>5 \mu \mathrm{m}\end{array}$} & \multirow{2}{*}{$\begin{array}{c}\text { Mean } \\
\text { total }\end{array}$} \\
\hline & & & & & & $0.2-5 \mu \mathrm{m}$ & $>5 \mu \mathrm{m}$ & & & & \\
\hline \multirow[t]{3}{*}{ A } & $\mathrm{C}$ & A1 & 15.1 & 13.6 & 34.2 & 5.0 & 16.3 & 1.6 & 2.1 & 0.7 & 0.9 \\
\hline & $\mathrm{C}$ & A2 & 15.4 & 13.3 & 35.0 & 5.8 & 63.2 & 5.3 & 5.4 & 0.9 & 1.0 \\
\hline & MS & A3 & 15.1 & 13.8 & 35.5 & 10.9 & 13.1 & 0.3 & 0.6 & 0.1 & 0.3 \\
\hline \multirow[t]{3}{*}{ B } & $\mathrm{C}$ & B1 & 13.5 & 12.8 & 35.2 & 4.0 & 9.0 & 0.6 & 0.7 & 0.2 & 0.3 \\
\hline & MS & B2 & 14.2 & 12.9 & 35.4 & 16.8 & 29.9 & 1.5 & 1.8 & 0.4 & 0.6 \\
\hline & $\mathrm{SC}$ & B3 & 13.8 & 13.0 & 35.5 & 34.6 & 5.2 & 0.1 & 1.2 & 0.1 & 0.5 \\
\hline \multirow[t]{2}{*}{$\mathrm{C}$} & $\mathrm{C}$ & $\mathrm{C} 1$ & 13.2 & 12.7 & 35.3 & 4.3 & 37.8 & 1.9 & 2.0 & 0.8 & 0.9 \\
\hline & MS & $\mathrm{C} 2$ & 15.6 & 13.3 & 35.3 & 5.5 & 19.0 & 0.8 & 0.8 & 0.2 & 0.3 \\
\hline \multirow[t]{3}{*}{$\mathrm{D}$} & $\mathrm{C}$ & D1 & 14.5 & 12.7 & 35.5 & 10.3 & 20.4 & 1.1 & 1.3 & 0.4 & 0.5 \\
\hline & MS & D2 & 13.8 & 12.9 & 35.2 & 9.4 & 19.4 & 1.0 & 1.3 & 0.3 & 0.4 \\
\hline & $\mathrm{SC}$ & D3 & 13.6 & 13.6 & 35.6 & 14.6 & 5.1 & 0.2 & 0.4 & 0.1 & 0.2 \\
\hline
\end{tabular}

showed downwelling of water at Stn B3 and upwelling at Stn D3. Secondly, a dome-shaped feature in the cross-shelf vertical distribution of nutrients (higher concentrations in the euphotic layer) was observed, which may be related to internal waves. Thirdly, an upwelling of deep water associated with the topography of the Avilés Canyon was also detected on the shelf.

\section{Food availability}

The phytoplankton community was dominated by the small size class $(0.2$ to $5 \mu \mathrm{m})$ in the saline slope current. This fraction accounted for 87 and $74 \%$ of total chl $a$ at Stns B3 and D3, respectively. However, phytoplankton composition in the coastal and mid-shelf areas comprised mostly large cells (>5 $\mathrm{mm}$ ) (55 to 92\% of total chl a biomass) for all transects (Table 1). Total phytoplankton biomass showed high variability throughout the study area, ranging between 13 and $69 \mathrm{mg}$ chl a m${ }^{-2}$. Subsurface (15 to $30 \mathrm{~m}$ ) chl $a_{\max }$ was detected at all stations.

Dinoflagellates (Prorocentrum spp., Gyrodinium spp., Gymnodinium spp., Dinophysis spp., Ceratium spp. or Protoperidinium spp.) dominated the microplankton community in both cell abundance and carbon concentration along Transects A and D (Table 2). Prorocentrum balticum accounted for $60 \%$ of dinoflagellate carbon at Stn A1. This photosynthetic species has been

Table 2. Microplankton abundance. Abundance is represented as the percentage (\%) of total microplankton cells, the mean (M) and the integrated (Int) concentration of cells in the euphotic layer. Abundance is also shown as carbon concentration integrated

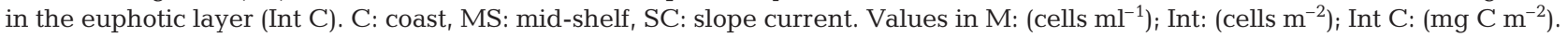

See 'Materials and methods' for euphotic layer depth

\begin{tabular}{|c|c|c|c|c|c|c|c|c|c|c|c|c|c|c|c|c|c|c|}
\hline \multirow{2}{*}{\multicolumn{2}{|c|}{ Transect Zone }} & \multirow[t]{2}{*}{ Stn } & \multicolumn{4}{|c|}{ Diatoms } & \multicolumn{4}{|c|}{ Dinoflagellates } & \multicolumn{4}{|c|}{ Ciliates } & \multicolumn{4}{|c|}{ Other groups } \\
\hline & & & $\%$ & M & Int & Int C & $\%$ & $\mathrm{M}$ & Int & Int $C$ & $\%$ & $\mathrm{M}$ & Int & Int $\mathrm{C}$ & $\%$ & $\mathrm{M}$ & Int & Int C \\
\hline \multirow[t]{3}{*}{ A } & $\mathrm{C}$ & A1 & 2 & 6 & 159 & 203.0 & 96 & 301 & 6702 & 5687.2 & 1 & 3 & 88 & 183.3 & 0 & 0 & 0 & 0 \\
\hline & $\mathrm{C}$ & A2 & 1 & 21 & 425 & 46.6 & 97 & 1150 & 30850 & 8312.1 & 1 & 17 & 476 & 395.8 & 0 & 0 & 0 & 0 \\
\hline & MS & A3 & 18 & 11 & 540 & 63.9 & 72 & 50 & 2212 & 555.3 & 4 & 3 & 116 & 89.1 & 6 & 4 & 197 & 26.0 \\
\hline \multirow[t]{3}{*}{ B } & $\mathrm{C}$ & B1 & 71 & 36 & 1588 & 536.3 & 17 & 10 & 385 & 196.0 & 9 & 5 & 190 & 206.8 & 3 & 1 & 64 & 8.4 \\
\hline & MS & B2 & 87 & 557 & 2953 & 4533.4 & 12 & 84 & 3913 & 1153.4 & 1 & 7 & 259 & 348.5 & 1 & 7 & 281 & 420.7 \\
\hline & $\mathrm{SC}$ & B3 & $<1$ & 1 & 31 & 37.1 & 1 & 27 & 1135 & 768.4 & $<1$ & 7 & 300 & 110.9 & & 2379 & 112700 & 485.9 \\
\hline \multirow[t]{2}{*}{$\mathrm{C}$} & $\mathrm{C}$ & $\mathrm{C} 1$ & 69 & 153 & 10242 & 2403.4 & 13 & 56 & 1898 & 889.4 & 1 & 4 & 222 & 563.4 & 17 & 52 & 2576 & 320.5 \\
\hline & MS & $\mathrm{C} 2$ & 18 & 72 & 6836 & 1377.8 & 15 & 62 & 5604 & 2443.0 & 63 & 242 & 23420 & 1962.9 & 3 & 13 & 1250 & 947.5 \\
\hline \multirow[t]{3}{*}{$\mathrm{D}$} & $\mathrm{C}$ & D1 & 26 & 41 & 2166 & 1444.9 & 46 & 99 & 3904 & 447.7 & 11 & 17 & 920 & 336.5 & 17 & 27 & 1432 & 68.0 \\
\hline & MS & D2 & 39 & 115 & 6079 & 677.6 & 57 & 145 & 8870 & 2945.3 & 3 & 6 & 424 & 725.5 & 2 & 5 & 258 & 55.2 \\
\hline & $\mathrm{SC}$ & D3 & 3 & 1 & 77 & 2.8 & 73 & 39 & 1692 & 297.2 & 17 & 8 & 385 & 153.5 & 7 & 2 & 162 & 33.4 \\
\hline
\end{tabular}


reported to form red tides in waters with low salinity (Edler at al. 1984), as occurred at Stn A1 (see Table 1). At stations of the slope saline current, dinoflagellates were mainly composed of small species of the family Gymnodiniaceae. Diatoms were the most important group in the coastal and mid-shelf waters of Transect B and at Stn C1 (Table 2), whereas they accounted for between 1 and $39 \%$ of the total microplankton in Transects A and D. Maximum diatom abundance was attained at Stn B2, where their concentration was more than 3 times higher than at the other stations. This maximum was due to Thalassiosira spp., mainly $T$. rotula, which represented $94 \%$ of the diatom cells and $96 \%$ of diatom carbon. A low diversity of diatoms was also observed at other stations with high diatom abundance; Nitzschia pungens represented $82 \%$ of total diatom abundance at Stn C1, Detonula pumila and Rhizosolenia delicatula represented $65 \%$ of diatom cells at Stn D1 and 3 species of Nitzschia and R. delicatula comprised $>95 \%$ of diatom abundance at Stn C2. The density of ciliates was generally low but they dominated the microplanktonic community at Stn C2. 'Other groups' were composed of Chrysophyceae, Cryptophyceae, Euglenophyceae and microflagellates. All these groups showed very low diversity (1 or 2 species) and were really scarce, except microflagellates at Stn B3, where they represented $99 \%$ of cell abundance but only $38 \%$ of microplankton carbon biomass (Table 2).

\section{Population status}

The distribution of Calanus helgolandicus and Calanoides carinatus populations were not related to food availability or physical factors (Fig. 3). For both species, the highest densities of females and total population were detected at Stn D2, although there was no clear pattern of abundance. Copepodites V and females were the dominant stages. Female abundance varied considerably between stations, ranging from 4 to 491 females $\mathrm{m}^{-3}$ for $C$. helgolandicus and from 12 to 748 females $\mathrm{m}^{-3}$ for C. carinatus (Fig. 3). Males were scarce or absent and the sex ratio was always biased towards females.

\section{Egg production rate}

The fecundity of both species followed the same coastal-ocean pattern, with the highest EPRs attained in the mid-shelf area, where significant differences between stations were found (Calanus helgolandicus: $F_{3,57}=3.96, \mathrm{p}<0.05$; Calanoides carinatus: $F_{3,56}=5.29$, $\mathrm{p}<0.01)$. C. helgolandicus females produced eggs at rates between $10 \pm 3$ eggs d $^{-1}$ at Stn A3 and $24 \pm 2$ eggs $\mathrm{d}^{-1}$ at Stn D2. C. carinatus fecundity ranged between $13 \pm 2$ eggs female ${ }^{-1} \mathrm{~d}^{-1}$ at Stn A3 and $28 \pm 3$ eggs female $\mathrm{e}^{-1} \mathrm{~d}^{-1}$ at Stn D2. In the coastal area there were no differences in fecundity between transects $(C$. helgo-

\section{Calanus helgolandicus}
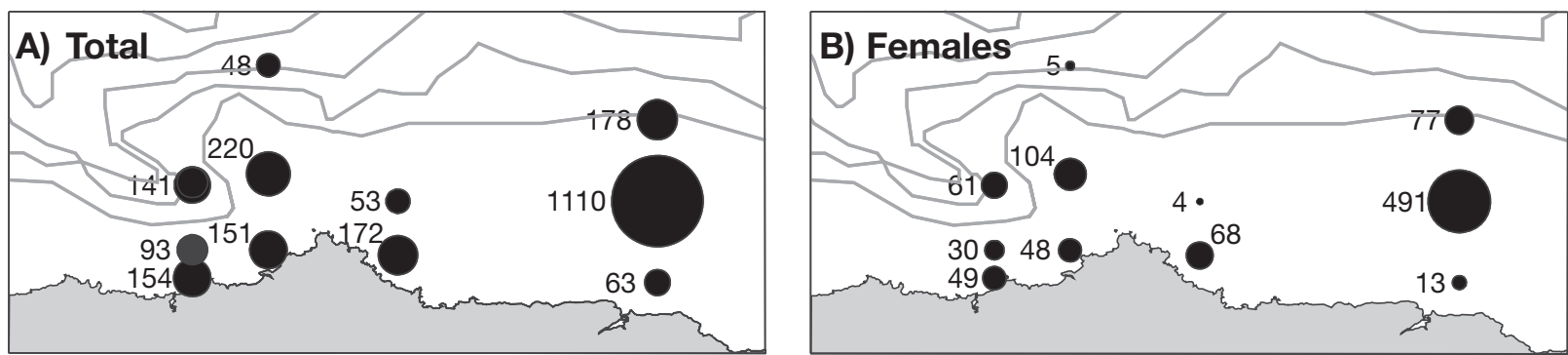

Calanoides carinatus
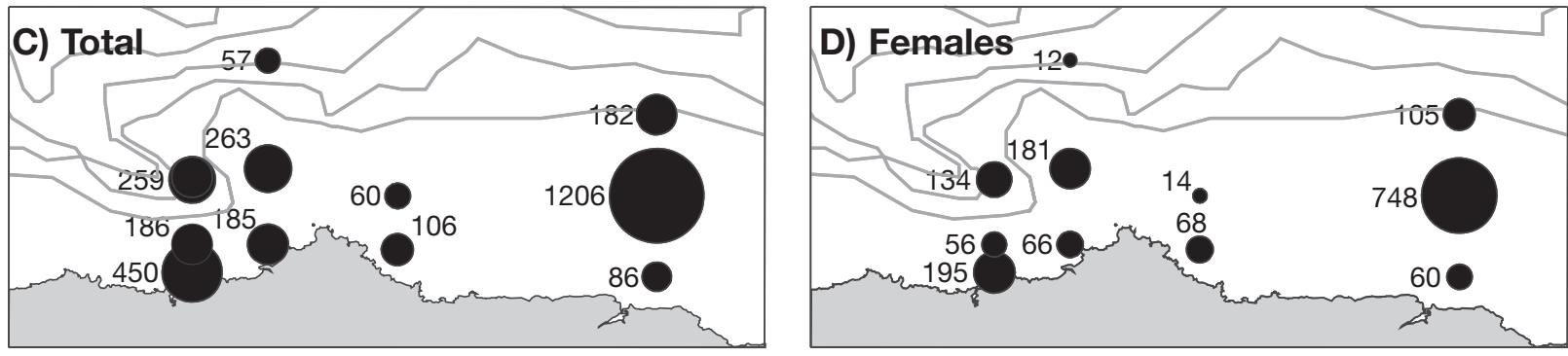

Fig. 3. Calanus helgolandicus and Calanoides carinatus. $(\mathrm{A}, \mathrm{C})$ Total and $(\mathrm{B}, \mathrm{D})$ female population abundance (CIV to adults, ind. $\mathrm{m}^{-3}$ ) during the Sardina cruise 
landicus: $F_{4,56}=1.99, \mathrm{p}>0.05 ; C$. carinatus: $F_{4,56}=184$, p > 0.05) and fecundity had intermediate values, i.e. 14 eggs female ${ }^{-1} \mathrm{~d}^{-1}$ for $C$. helgolandicus and 16 eggs female ${ }^{-1} \mathrm{~d}^{-1}$ for $C$. carinatus. Females produced eggs at low rates (mean value of 1 egg $\mathrm{d}^{-1}$ ) in stations in the offshore saline current, with no difference in C. helgolandicus egg production between stations ( $t$-test, $\left.T_{18}=1.68, p>0.05\right)$. C. carinatus did show a difference in egg production at these stations $\left(T_{15}=2.75, \mathrm{p}<0.05\right)$ with $8 \pm 3$ eggs female ${ }^{-1} \mathrm{~d}^{-1}$ at Stn B3 and $0.3 \pm 0.2$ eggs female $\mathrm{f}^{-1}$ at Stn D3.

The lowest percentage of spawning and CS were found at the slope saline current (Fig. 4). The average percentage of spawning females in mid-shelf was $80 \%$ for Calanus helgolandicus and $98 \%$ for Calanoides carinatus. In nearshore waters, fewer females produced eggs than in mid-shelf zones, the overall means for coast being $70 \%$ for C. helgolandicus and $80 \%$ for C. carinatus (Fig. 4). The mean CS was similar for mid-shelf and coastal waters (around 20 eggs female $\mathrm{f}^{-1} \mathrm{~d}^{-1}$; for all shelf and coastal stations CS ranged between 15 and 26 eggs female f $^{-1}$ $\mathrm{d}^{-1}$ for $C$. helgolandicus and between 16 and 25 eggs female $^{-1} \mathrm{~d}^{-1}$ for C. carinatus (Fig. 4). The maximum individual EPR was found nearshore on Transect D, with 54 eggs d $\mathrm{d}^{-1}$ for C. helgolandicus and 49 eggs d $^{-1}$ for C. carinatus.

For both species, the mean population production rates were highest for the mid-shelf station group and lowest for the saline current station group (Table 3); the overall mean population egg production was the same for both species $\left(T_{15}=0.71, p>0.05\right)$. There were no environmental factors that explained the variability in population production rates $(p>0.05$ for regression analysis with temperature and copepod food concentration as the independent variable).

\section{Egg production and food availability}

The relationship between EPR of both species showed a saturation response with diatom concentration (Fig. 5A). This relationship explained 89 and $62 \%$ of the variability in egg production for Calanus helgolandicus and Calanoides carinatus. The EPR of C. carinatus also showed a functional response with the concentration of chl a $>5 \mu \mathrm{m}$, although the coefficient of determination was lower $\left(\mathrm{R}^{2}=0.53\right)$ A saturation response of $\mathrm{CS}$ to diatom concentration was also observed $\left(\mathrm{R}^{2}=0.80\right.$ for both species). We have run similar analyses, using linear regressions and the Ivlev function with the remaining descriptors of food availability (total chl $a$, dinoflagellates, ciliates, etc.), but interestingly no other significant relationships between EPR and food availability were found.
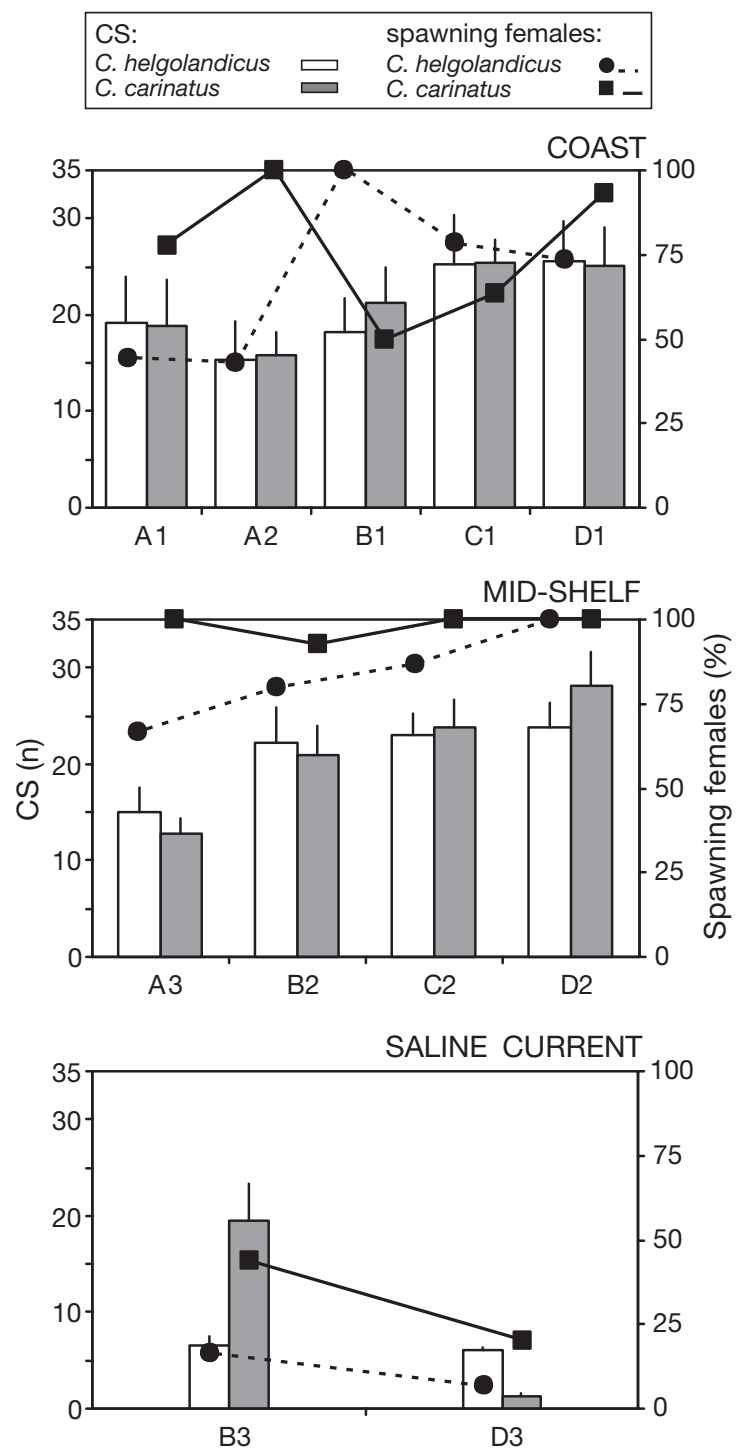

Fig. 4. Calanus helgolandicus and Calanoides carinatus. Reproductive response of females for coastal, mid-shelf and saline slope current stations. Spawning females is given in \% and clutch size $(\mathrm{CS})$ is given in mean number of eggs ( $\pm 1 \mathrm{SE}$ )

Table 3. Calanus helgolandicus and Calanoides carinatus. Population production rates. Values are shown as range of coastal, mid-shelf and slope saline current stations

\begin{tabular}{|lcc|}
\hline & \multicolumn{2}{c|}{ Production rate } \\
& Eggs $\left(\mathrm{m}^{-3} \mathrm{~d}^{-1}\right)$ & Carbon $\left(\mu \mathrm{C} \mathrm{m}^{-3} \mathrm{~d}^{-1}\right)$ \\
\hline C. helgolandicus & & \\
Coast & $196-1347$ & $66.9-455.4$ \\
Mid-shelf & $81-12000$ & $27.6-3900$ \\
Slope current & $9-31$ & $3.1-10.4$ \\
C. carinatus & & \\
Coast & $703-2858$ & $28.5-517$ \\
Mid-shelf & $336-21000$ & $61.9-3900$ \\
Slope current & $28-99$ & $5.1-18$ \\
\hline
\end{tabular}



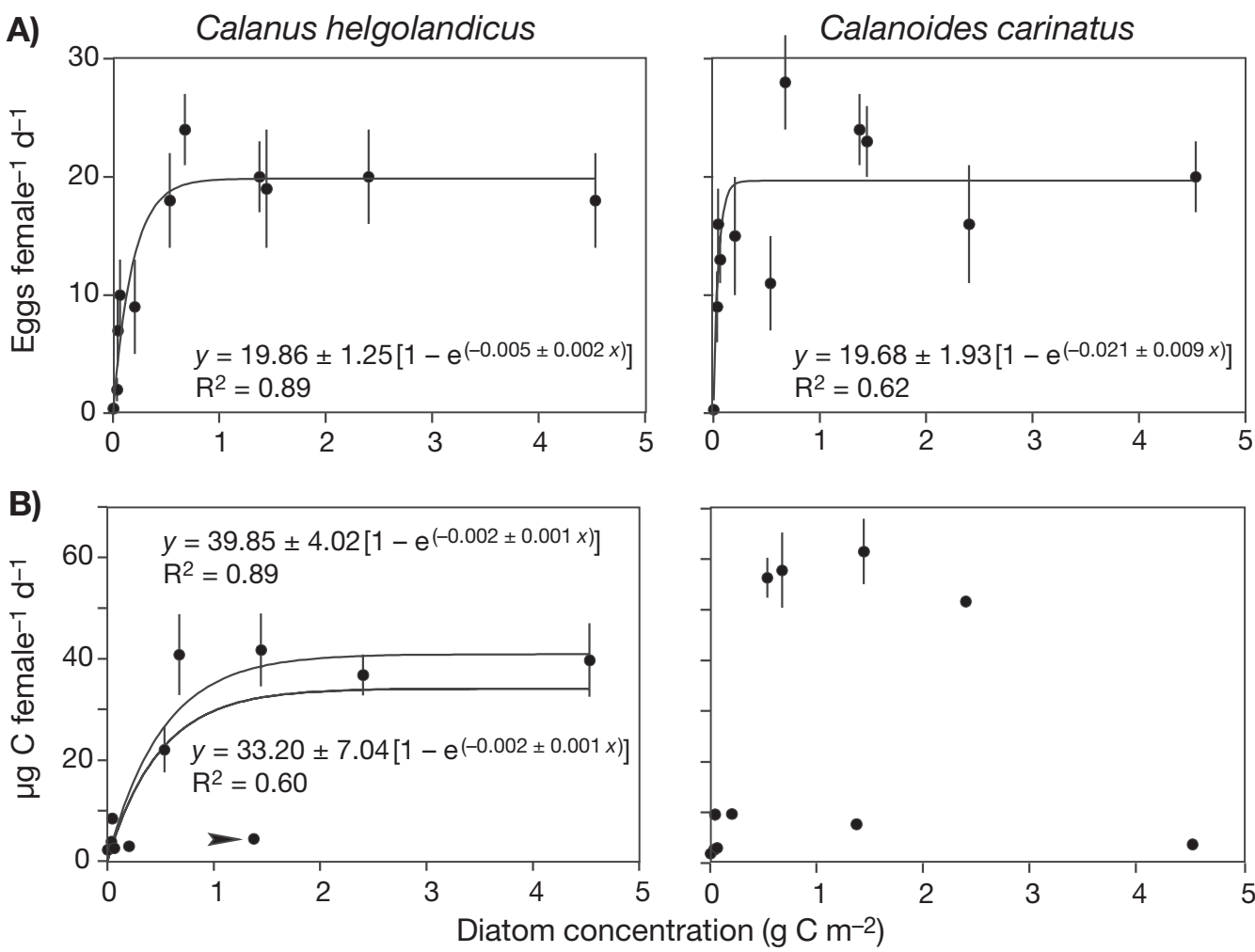

Fig. 5. Calanus helgolandicus and Calanoides carinatus. Relationship between diatom concentration and (A) egg production rate and (B) ingestion rate. Relationship between ingestion rate of C. helgolandicus and diatom concentration is shown excluding Stn C2 (arrowhead) (see 'Results' for more details). Data are mean $\pm 1 \mathrm{SE}$

\section{Female gonad maturation stage, mass and lipid reserves}

The RI attained high values (80 to $90 \%$ ) at most stations and was always higher than $50 \%$, except at the slope current station (Stn D3), where the percentages of females in the spawning state were 32 and $37 \%$ for Calanus helgolandicus and Calanoides carinatus, respectively. Moreover, there was a positive relationship between RI and spawning percentage (for C. helgolandicus: $\mathrm{R}^{2}=0.62, \mathrm{p}<0.01, \mathrm{~N}=11$; for $C$. carinatus: $\mathrm{R}^{2}=0.50, \mathrm{p}<0.05, \mathrm{~N}=11$ ). For both species, all the females analysed for gonad development had full spermatheca, indicating that they were fertilized. Only 6 out of 880 females analysed were senescent. These results suggest an active reproduction season.

The carbon content of Calanus helgolandicus females showed no differences between zones (Kruskal-Wallis test, $H_{9}=14.32, \mathrm{p}>0.05$ ) with an overall mean of $88.3 \pm$ $11.5 \mu \mathrm{g} \mathrm{C}$ female $^{-1}$, whereas the biomass of Calanoides carinatus females changed between stations $\left(H_{9}=\right.$ 16.23, $\mathrm{p}<0.05$ ), ranging from 40.6 to $56.9 \mu \mathrm{g} \mathrm{C}$ fe$\mathrm{male}^{-1}$. However, this difference in biomass had no effect on EPR, since the parameters were not related $\left(R^{2}=\right.$ $0.29, \mathrm{p}>0.05, \mathrm{~N}=11$ ). The $\mathrm{C}: \mathrm{N}$ ratio was similar for spe- cies and ranged from 3.6 to $4.5(3.9 \pm 0.1)$ for $C$. helgolandicus and from 3.8 to $4.4(3.9 \pm 0.1)$ for $C$. carinatus.

Calanus helgolandicus females had no visible lipid sac at Stns A1 and B1, but they had several tiny drops scattered along the cephalothorax. At the remaining stations, more than $70 \%$ of females had oil sacs. For Calanoides carinatus, 80 to $93 \%$ of the females had oil sacs, except at Stn A2, where females had only oil drops. Lipid storage of $C$. carinatus was higher than that of $C$. helgolandicus only as relative WE content values (Table 4). In addition, the oil sacs of $C$. carinatus females were darker in colour. Lipid storage of both species varied between stations $\left(F_{8,103}=11.49, \mathrm{p}<0.01\right.$ for $C$. helgolandicus; $F_{9,102}=7.94, p<0.01$ for $C$. carinatus). The post-hoc Tukey test separated the stations into 2 groups: one for Stns A3 and C2, which had the highest values, and another one for the remaining stations (Table 4).

\section{Herbivorous feeding of females}

Gut pigment content (GPC) and ingestion rate of Calanoides carinatus females showed a coastal-ocean gradient, reaching the highest values at the coastal sta- 
Table 4. Calanus helgolandicus and Calanoides carinatus. Oil sac volume, lipid content as wax ester (WE) and relative lipid content (WE/prosome volume) of females. Stations are separated into 2 groups according to results of the post-hoc test (see 'Results; Female gonad maturation state, mass and lipid reserves'). Data are minimum and maximum values

\begin{tabular}{|lccc|}
\hline & $\begin{array}{c}\text { Oil sac vol. } \\
\left(10^{6} \mu \mathrm{m}^{3}\right)\end{array}$ & $\begin{array}{c}\text { WE } \\
(\mu \mathrm{g} \mathrm{C})\end{array}$ & $\begin{array}{c}\text { Relative } \\
\text { WE }\end{array}$ \\
\hline Stns A3 and C2 & & & \\
C. helgolandicus & $13.8-21.3$ & $6.4-9.9$ & $4.3-6.8$ \\
$\begin{array}{l}\text { C. carinatus } \\
\text { Other stations }\end{array}$ & $13.7-15.5$ & $6.6-9.1$ & $8.4-9.6$ \\
C. helgolandicus & $4.4-6.1$ & $2.1-2.8$ & $1.2-1.8$ \\
C. carinatus & $2.2-4.9$ & $1.0-2.2$ & $1.1-2.3$ \\
\hline
\end{tabular}

tions (Table 5). For Calanus helgolandicus, the mean values for the coastal and mid-shelf areas were very similar, and the lowest herbivorous feeding activity was also measured in the slope saline current. The ingestion rate expressed as the daily ratio of body weight ranged between 2.5 and $46.5 \%$ body carbon $\mathrm{d}^{-1}(19.8 \pm 5.5)$ for $C$. helgolandicus and between 4.2 and $125.5 \%$ body carbon $\mathrm{d}^{-1}(45.5 \pm 15.5)$ for C. carinatus. For both species the highest and lowest GPC and ingestion rates were attained at Stn D1 (coast) and Stn D3 (slope saline current), respectively (Table 5). The relationship between the ingestion rate of $C$. helgolandicus and diatom concentration showed a type II functional response (Fig. 5B). At Stn C2 the ingestion rate was lower than expected, and ciliates were the most abundant microplankton group (Table 2, Fig. 5B). If Stn $\mathrm{C} 2$ is omitted, the coefficient of determination increases from 0.60 to 0.89 . No other significant relationships were found between $C$. helgolandicus feeding rate and the remaining parameter used to describe the copepods' food environment (i.e. total chl $a$, chl $a$ > $5 \mu \mathrm{m}$ and the abundance of the remaining phytoplankton groups). Interestingly, the ingestion rate of C. carinatus was not related to food availability. CS and herbivore feeding rates were positively correlated for both species $(\mathrm{r}=0.67$ and $0.65, \mathrm{p}<0.05$, for $C$. helgolandicus and C. carinatus, respectively).

\section{DISCUSSION}

\section{Food availability, herbivorous feeding and egg production}

The potential food conditions for females in the slope saline current differed clearly from those observed at coastal and mid-shelf stations (González-Quirós et al. 2004). Phytoplankton was dominated by the small size fraction in the slope current and, thus, the microbial food web prevailed there, which is in agreement with
Table 5. Calanus helgolandicus and Calanoides carinatus. Gut pigment content (GPC, in ng chl a female ${ }^{-1} \mathrm{~d}^{-1}$, mean $\pm 1 \mathrm{SE}$ ) and ingestion rate (in $\mu \mathrm{g} \mathrm{C}$ female $\mathrm{e}^{-1} \mathrm{~d}^{-1}$ ) for coastal, mid-shelf and saline slope current stations

\begin{tabular}{|lccc|}
\hline & \multirow{2}{*}{ GPC } & \multicolumn{2}{c|}{ Ingestion rate } \\
& & & \\
& & & \\
& & & \\
C. helgolandicus & & 21.8 & $2.9-40.7$ \\
Coast & $2.9 \pm 1.0$ & 21.3 & $2.5-39.8$ \\
Mid-shelf & $2.8 \pm 1.4$ & 3.0 & $2.2-3.8$ \\
Slope current & $0.4 \pm 0.1$ & & \\
C. carinatus & & 37.3 & $9.4-60.4$ \\
Coast & $5.0 \pm 1.6$ & 17.7 & $3.0-56.8$ \\
Mid-shelf & $2.4 \pm 1.8$ & 2.2 & $1.9-2.6$ \\
Slope current & $0.4 \pm 0.1$ & & \\
\hline
\end{tabular}

previous findings (Fernández et al. 1993). In contrast, large cells (diatoms and dinoflagellates) were predominant in the coastal and mid-shelf zones, suggesting the importance of the classical food chain (e.g. Cushing 1989). The typical situation for the central Cantabrian Sea under post-bloom conditions, when the water stratification has just started, is that dinoflagellates dominate the microplankton community (Fernández \& Bode 1994), as we found at several stations along the shelf, but the nutrient input induced by the mesoscale structure also allowed diatoms to attain high abundance in coastal and mid-shelf waters. Therefore, high abundances of dinoflagellates and diatoms prevailed simultaneously in nearshore waters.

The 2 kinds of food webs found during the cruise induced different reproductive responses in Calanoides carinatus and Calanus helgolandicus. In the slope current, food availability was scarce due to the low concentration of large phytoplankton. Consequently, the ingestion of phytoplankton was lowest in this area because of the low efficiency of large calanoids feeding on small phytoplankton cells (e.g. Hansen et al. 1994). Given the general relationship between egg production and diatom abundance observed during the cruise, the low fecundity of both species may be linked to the scarcity of diatoms there. This is more evident for $C$. helgolandicus, since the general relationship between ingestion rate and diatom concentration suggests that this species may select for diatoms. At the salinity current stations only a few females spawned because few females had mature oocytes, and the CSs were low. This is in agreement with previous works that showed that reproduction of Calanus finmarchicus (Båmstedt et al. 1999), C. carinatus and C. helgolandicus (Armstrong et al. 1991, Ceballos et al. 2004) is food limited when the phytoplankton assemblage is dominated by small algae in sub-bloom concentrations. Therefore, food concentration and its size distribution appear to be the main constraint on egg production in the saline current. 
In the slope current the ingestion of phytoplankton by Calanoides carinatus and Calanus helgolandicus females was insufficient to meet their carbon demands (Table 6). Moreover, although fecundity and herbivorous feeding were positively related for both species during the cruise, the ingestion of phytoplankton did not explain ca. $35 \%$ of the variability in fecundity. Therefore, females needed to use alternative food items to obtain supplementary carbon, and a mixed diet could be argued. The microbial food web could sustain copepod populations through the heterotrophic protozoa (Sherr \& Sherr 1994). Ciliates and nonautotrophic dinoflagellates might be a good alternative prey when phytoplankton is dominated by small cells (e.g. Nielsen et al. 1993). Furthermore, Calanus spp. generally prey on ciliates and heterotrophic dinoflagellates more efficiently than on phytoplankton because

Table 6. Calanus helgolandicus and Calanoides carinatus. Daily carbon requirements (in $\mu \mathrm{g} \mathrm{C}$ female $\mathrm{e}^{-1} \mathrm{~d}^{-1}$ ) for egg production rate (EPR) and basal metabolism (respiration, $R$ ) and percentage of requirements covered by ingestion on phytoplankton $\left(\mathrm{C}_{\text {ing }} / \mathrm{C}_{\text {req }}\right)$ for coastal, mid-shelf and saline slope current stations. $R$ was calculated according to Ikeda et al. (2001). Our $R$ ranged between 0.38 and $0.45 \mu \mathrm{O}_{2}$ female $^{-1} \mathrm{~h}^{-1}$ for C. helgolandicus, and between 0.26 and $0.32 \mu l \mathrm{O}_{2}$ female ${ }^{-1} \mathrm{~h}^{-1}$ for $C$. carinatus. Carbon requirements for metabolism were estimated as $\mathrm{C}=R \times \mathrm{RQ} \times(12 / 22.4)$ using a $\mathrm{RQ}$ (respiratory quotient) of 0.97 (Omori \& Ikeda 1984). Carbon requirements for egg production were estimated by multiplying EPR per egg carbon content and applying a gross growth efficiency of $30 \%$

\begin{tabular}{|c|c|c|c|c|}
\hline \multirow[t]{2}{*}{ Zone } & \multirow[t]{2}{*}{ Stn } & \multicolumn{2}{|c|}{$\mathrm{C}$ requirements } & \multirow[t]{2}{*}{$\mathrm{C}_{\mathrm{ing}} / \mathrm{C}_{\mathrm{req}}$} \\
\hline & & & EPR & \\
\hline \multicolumn{5}{|c|}{ C. helgolandicus } \\
\hline \multirow[t]{5}{*}{ Coast } & A1 & 5.3 & 9.5 & 19.8 \\
\hline & A2 & 4.7 & 7.4 & 68.2 \\
\hline & B1 & 5.7 & 19.8 & 84.3 \\
\hline & $\mathrm{C} 1$ & 6.2 & 22.2 & $>100$ \\
\hline & D1 & 5.3 & 20.6 & $>100$ \\
\hline \multirow[t]{4}{*}{ Mid-shelf } & A3 & 6.0 & 10.8 & 15.1 \\
\hline & B2 & 6.0 & 19.9 & $>100$ \\
\hline & $\mathrm{C} 2$ & 5.0 & 22.8 & 15.6 \\
\hline & D2 & 5.4 & 26.4 & $>100$ \\
\hline \multirow[t]{2}{*}{ Slope current } & B3 & 5.6 & 2.0 & 50.3 \\
\hline & D3 & 5.2 & 0.4 & 38.7 \\
\hline \multicolumn{5}{|l|}{ C. carinatus } \\
\hline \multirow[t]{5}{*}{ Coast } & A1 & 4.0 & 26.3 & 31.4 \\
\hline & A2 & 3.7 & 28.7 & 29.1 \\
\hline & B1 & 4.0 & 19.2 & $>100$ \\
\hline & $\mathrm{C} 1$ & 3.9 & 29.3 & $>100$ \\
\hline & D1 & 3.9 & 42.9 & $>100$ \\
\hline \multirow[t]{4}{*}{ Mid-shelf } & A3 & 3.8 & 22.8 & 11.2 \\
\hline & B2 & 3.8 & 36.0 & 9.2 \\
\hline & $\mathrm{C} 2$ & 3.6 & 43.7 & 15.9 \\
\hline & D2 & 3.8 & 51.7 & $>100$ \\
\hline \multirow[t]{2}{*}{ Slope current } & B3 & 3.6 & 15.2 & 13.7 \\
\hline & D3 & 3.2 & 0.5 & 50.6 \\
\hline
\end{tabular}

their fast mobility increases encounter rates and thus capture efficiency (Levinsen et al. 2000). Hence, females could gain a nutritional advantage which may help to ensure survival by preying on protozoa, even when they are not highly abundant. However, this heterotrophic assemblage may not have been adequate for egg production because egg production is more nutritionally demanding than female basal metabolism. It should be also considered that our feeding rates are conservative values (see 'Materials and methods'), and that this fact may help to explain herbivore feeding which is not sufficient to support carbon demands.

The food resources available in the saline current were apparently not suitable for the population EPR. Applying an annual mean egg hatching success of $82 \%$ for Calanus helgolandicus and $71 \%$ for Calanoides carinatus, obtained at 2 stations close to the study area (Ceballos \& Álvarez-Marqués 2006), the potential recruitment was only 8 to 25 nauplii $\mathrm{d}^{-1} \mathrm{~m}^{-3}$ for C. helgolandicus and 20 to 71 nauplii $\mathrm{d}^{-1} \mathrm{~m}^{-3}$ for $C$. carinatus.

Primary production and phytoplankton biomass at coastal and mid-shelf stations were similar to levels measured in the early spring bloom in these waters (González-Quirós et al. 2004). These conditions seemed to enhance the production of both species, compared with that in the slope saline current. The mean EPR at the coast and mid-shelf was similar to EPRs measured during the productive seasons in the study area (Ceballos \& Álvarez-Marqués 2006) and adjacent areas (e.g. Pond et al. 1996). Although female ingestion rates were higher in nearshore waters than at the slope current stations, the carbon requirement for respiration and egg production was almost fulfilled by herbivorous feeding at only 4 or 5 stations in this zone, for Calanus helgolandicus and Calanoides carinatus, respectively, and a big deficit was found at some other stations (Table 6). As proposed for the saline current, protozoa could also have provided an alternative prey for females, for example at Stn C2, where ciliates were abundant. Interestingly, there was no indicator of potential food that directly explained herbivorous ingestion by $C$. carinatus. However, the relationship between diatoms and egg production described here, as well as previous information on the importance of diatoms for C. carinatus ingestion and production (Smith 2001), indicates that females could feed actively on diatoms. C. carinatus shows a high selectivity on a species basis, and the highest rates were found in assemblages dominated by Nitzschia delicatissima and Rhizosolenia styliformis (Smith 1995). In agreement with this, stations where ingestion rates were highest during our cruise were characterised by moderately high or high diatom abundance and high concentrations of Nitzschia spp. and Rhizosolenia spp. The selective feeding behaviour of copepods is enhanced in situations with low food diver- 
sity (Turner \& Tester 1989), so C. carinatus would probably have selected these diatom species during the cruise. This may also explain why the $C$. carinatus ingestion rate did not show high variability between the remaining stations, even though diatom concentration did (see Fig. 5).

EPR of both species showed a saturation response to diatom concentration. This relationship was also observed for Calanus helgolandicus ingestion. The highest carbon ingestion rates by $C$. helgolandicus and Calanoides carinatus found in the present study were in the upper range of those reported in the literature (see Tables $19 \& 21$ in Mauchline 1998). In terms of ingestion on chl $a$, although we found some very high values, they were not close to the maximum values previously reported for Calanus spp. or C. carinatus. This is due to the fact that most of the authors used the standard ratio $\mathrm{C}: \mathrm{chl} a$ of 50 , whereas we used a higher ratio, which was measured during the cruise, and similar to other in situ ratios (e.g. Irigoien et al. 2000).

Although EPRs of both species attained high values at several stations, a comparison of the maximum EPR found here with previously reported in situ maximum rates (>50 eggs female ${ }^{-1} \mathrm{~d}^{-1}$, e.g. in Laabir et al. 1998 for Calanus helgolandicus and $>60$ eggs female ${ }^{-1} \mathrm{~d}^{-1}$, e.g. in Richardson et al. 2001 for Calanoides carinatus) implies that both species were far from saturation. Moreover, Poulet et al. (1996) pointed out that the food concentration needed to obtain a saturation response in egg production for $C$. helgolandicus ranged between 80 and $250 \mu \mathrm{g} \mathrm{C}^{-1}$, and we had only about $13 \mu \mathrm{g} \mathrm{C}^{-1}$. Accordingly, the saturation relationship between egg production and diatoms is somewhat surprising, because it seems that something not related to physiological constraints was slowing EPR down at stations with a high diatom abundance. It is possible that a non-suitable food may explain these results. At low food concentrations, the egg production of copepods is limited by the quantity rather than by the quality of the food, whereas at high concentration, food quantity is important only if food is not diverse enough to compensate for poor nutritional value (Guisande et al. 2000, and references therein). Assuming that females fed mainly on diatoms, egg production would have been limited by food quantity at those stations with low diatom concentrations, whereas high diatom concentration would have induced an increase in egg production. Nevertheless, at stations with the highest diatom concentration (where functional response saturates), the diatom diversity was very low and, therefore, egg production may have been limited due to a nearly mono-specific diet. Several studies have screened diatom species and examined the role of essential nutrients (e.g. fatty acids and amino acids) in an attempt to explain why copepod fecundity is some- times low when animals feed on certain species of diatoms, although the results to date are not consistent (e.g. Lacoste et al. 2001, Pohnert et al. 2002). Different field studies have shown that some diatoms may depress copepod recruitment by producing secondary metabolites that reduce egg production and/or egg hatching success (Miralto et al. 2003, Ianora et al. 2004). We cannot rule out the possibility that some species of diatoms were able to produce these kinds of toxins at the stations where functional response saturated. In addition, silica frustules of the diatoms could hinder its ingestion (Besiktepe \& Dam 2002); as a consequence, a diet based mostly on diatoms might lead to a reduction in assimilation efficiency.

\section{Lipid reserves and egg production}

The egg production recorded during our cruise seems to be supported exclusively by freshly ingested food and not by lipid reserves. Lipid storage of Calanus helgolandicus and Calanoides carinatus females was low compared with previous data (Rey-Rassat et al. 2002a,b for C. helgolandicus and Arashkevich \& Drits 1997 for C. carinatus). The C:N ratio of females suggests low lipid reserves and a protein-based metabolism (Tande 1982, and references therein). Female lipid reserves were highest at Stns A3 and C2 and it is likely that females at these stations had better food conditions during development and growth, which enhanced lipid deposition. It is also possible that the advection process had moved copepods from one place to another during the time when lipid deposition occurred, explaining the high lipid content at these 2 stations and the same amount of lipid reserves at the remaining ones. However, this difference in lipid deposition between stations did not result in differences in reproduction.

Calanoides carinatus lipid stores are used during gonad development in the CV stage and, therefore, partially, to produce the first eggs of young females (Arashkevich et al. 1996); however, there is no information to date on lipid support of egg production after that stage. In fact, $C$. carinatus shows a strong relationship between current feeding and egg production, responding to the availability of food in the previous $24 \mathrm{~h}$ (Huggett 2001). The low lipid content of females found here should not be a constraint for egg production. Moreover, low lipid storage in C. carinatus females was consistent with the use of lipids to fuel gonad development, since females have mature gonads with oocytes in Vitellogenesis II. This may also be valid for Calanus helgolandicus, but this species needs both good current conditions and a buffer of lipids to produce at high rates during the entirety of its spawning 
life (Rey-Rassat et al. 2002b). The low WE content of $C$. helgolandicus found during the cruise could hence be a limiting factor for fecundity. This may help us to understand why egg production was not maximum and explain the relationship between egg production and ingestion rates with diatom concentration. High food levels (i.e. here high diatom concentrations) could not compensate for the constraints that low lipid reserves of $C$. helgolandicus females placed on fecundity, since lipid reserves could limit the egg production even at stations with sufficient food to attain high ingestion rates. This explanation agrees with ReyRassat et al. (2002b), who underlined the importance of evaluating the environmental conditions not only at the time of sampling but also those in the recent past as well as the growth history of the females. Hence, estimates of lipid storage should be made routinely to help understand the in situ egg production of species such as $C$. helgolandicus. The egg production of C. helgolandicus was measured in the central Cantabrian Sea in May 1996 by González-Quirós et al. (2003). Although they found high phytoplankton biomass, the EPRs showed low values that were uncorrelated to the phytoplankton biomass. Low lipid reserves could help us to explain this result, but unfortunately, lipid stores were not measured in this work. Finally, we cannot exclude the possibility that $C$. carinatus females use lipid storage in the same way $C$. helgolandicus does in the Cantabrian Sea; more work is needed to understand the role of $C$. carinatus lipid reserves outside African upwelling systems.

\section{Productive late spring conditions and population recruitment of Calanus helgolandicus and Calanoides carinatus}

The mesoscale structures found during our study may be a regular phenomenon at the end of the spring season (González-Quirós et al. 2004), and the resulting extra time for production after the spring bloom would provide several advantages for copepod annual recruitment. Firstly, females can produce eggs over a longer period. Secondly, these conditions may enhance naupliar survival. The risk of starvation for young stages born during the spring blooms is high due to the short duration of these blooms. It has been suggested that the best time for naupliar birth is before the spring bloom onset because this ensures a suitable food supply during the whole period of development and growth (e.g. Melle \& Skjoldal 1998). Accordingly, conditions that prolong the spring bloom, such as were found here, may reduce nauplii starvation. Thirdly, late copepodite stages may be able to take advantage of the long period of high food conditions by storing lipid reserves that allow them to develop into a successful overwintering generation. In the present study, for example, the late copepodites (CIV and CV) had large, bright orange lipid sacs extending longitudinally and ventrally through the cephalothorax at all stations (data not shown).

There is not much information on overwintering strategies of Calanoides carinatus and Calanus helgolandicus populations in the Cantabrian Sea. In the northwest African upwelling areas, C. carinatus is known to diapause, as Stage V copepodites, in deep waters during the non-upwelling season and to inhabit surface waters only during the upwelling (e.g. Binet \& Suisse de Sainte Claire 1975). However, in northern Benguela, where upwelling is also seasonal, C. carinatus inhabits continental shelf waters throughout the year; its population consists of active individuals that feed and reproduce in surface waters over the shelf and the slope, and of diapausing Stage V copepodites in the deep oceanic waters. During the non-upwelling season active individuals appear in lower numbers (Timonin et al. 1992, Arashkevich et al. 1996). Given this, it is likely that during winter at least a fraction of the $C$. carinatus population in the central Cantabrian Sea undergo diapause in oceanic waters. The dormancy phase in Calanus spp. has been well established for many species (see review in Hirche 1996), although for $C$. helgolandicus there is no clear evidence of it for populations that inhabit coastal waters. However, a diapause phase during Stage CV in deep waters seems to be feasible for offshore populations (e.g. Williams \& Conway 1988, Andersen et al. 2001). Williams \& Conway $(1982,1984)$ showed that the overwintering stock in shallow waters off the Celtic Sea shelf consists of adults and Stage V copepodites distributed homogeneously throughout the water column. These animals showed low metabolic rates but fed and probably produced eggs. Hirche (1983) also showed that some Calanus finmarchicus populations remain in shallow waters and fiords during winter, the copepods exhibiting reduced metabolism but not yet total diapause. Similarly, Durbin et al. (1997) reported continuous reproduction of $C$. finmarchicus during winter in the Gulf of Maine. This might also occur in the central Cantabrian Sea. A mixed strategy that includes a first resting stock at the end of the spring bloom and an active population at the surface during summer, which in turn produces a second resting stock, might also be possible. In this case, the high lipid stores, accumulated during the extended productive springtime, may allow copepodites to survive during the subsequent and prolonged summer, when food resources are not suitable. In the Cantabrian Sea, light conditions are still favourable at the end of summer, and the breaking of the thermal stratification induces an input of nutri- 
ents into the euphotic layer, leading to an autumn phytoplankton bloom (Fernández \& Bode 1991). If a large number of $C$. helgolandicus and $C$. carinatus individuals were able to survive until this time in a good nutritional condition, a successful reproductive event associated with the autumn bloom might occur. This could lead to a large winter surface population and/or a large diapause stock.

An interesting result of our study was the lack of a pattern in the spatial distribution of the population production rates of Calanus helgolandicus and Calanoides carinatus. This was because egg production was correlated with food availability, but abundances were not related to any environmental parameter. The uncoupling of primary producers and herbivorous biomass has been observed before, for example, in Mediterranean copepod populations (Calbet et al. 2002, and references therein). It can be argued that a number of factors such as predation or advection may explain this result. Nevertheless, during our cruise the distribution of the more important fish larval species (e.g. sardine and mackerel), as well as of other copepod predators such as chaetognaths, was uncoupled from $C$. carinatus and C. helgolandicus population abundance (data not shown). Processes resulting in the importation/exportation of animals cannot be ruled out, but the presence of the subsurface saline slope current and its associated saline front would restrict the ocean-coast transport of animals; transport parallel to the coast may be feasible however. In fact, a general eastern transport of water along the slope during the cruise was described (González-Quirós et al. 2004).

González-Quirós et al. (2004) proposed that, given the high values of large phytoplankton production and of mesozooplankton biomass found on the continental shelf, the mesoscale features that occur during the late spring might have an important influence on the energy flow towards higher trophic levels (fish) after the phytoplankton spring bloom in coastal areas. In this paper, we show that the reproductive activity of 2 large herbivorous copepods suggests that they may efficiently exploit the high biomass of large phytoplankton cells induced by these mesoscale structures, so our results seem to complement the findings of these authors.

Acknowledgements. This study was supported by the project 1FD97-1045-C02-01 (Spanish Government under the EU FEDER program), and by a pre-doctoral fellowship (Plan de $\mathrm{I}+\mathrm{D}+\mathrm{I}$ ) of the Government of Principado de Asturias (Spain) awarded to S.C. Thanks to Dr. E. Head, Dr. R. GonzálezQuirós, Dr. J. Huggett, Dr. A. Isla and 3 anonymous reviewers for their valuable comments on the manuscript. We are grateful to our cruise mates for their help with sampling. Thanks also to E. Cabal for CNH analysis.

\section{LITERATURE CITED}

Álvarez-Marqués F (1982) Study of the planktonic copepods off the Gijón coastal area (Asturias). PhD thesis, University of Oviedo, Oviedo (in Spanish)

Álvarez-Marqués F (1984) The family Calanidae (Copepoda, Calanoida) in the Asturias coastal waters. Systematic, biometry and seasonal dynamics. Rev Biol Univ Oviedo 2: 107-119 (in Spanish)

Andersen V, Gubanova A, Nival P, Ruellet T (2001) Zooplankton community during the transition from spring bloom to oligotrophy in the open NW Mediterranean and effects of wind events. 2. Vertical distribution and migration. J Plankton Res 23:243-261

Arashkevich EG, Drits AV (1997) Ecological-physiological indices of Calanoides carinatus (Krøyer) from the Benguela upwelling region: biochemical composition, respiration rate, and gonad development of various life stages. Oceanology 37:513-519

Arashkevich EG, Drits AV, Timonin AG (1996) Diapause in the life cycle of Calanoides carinatus (Krøyer), (Copepoda, Calanoida). Hydrobiologia 320:197-208

Armstrong DA, Verheye HM, Kemp AD (1991) Short-term variability during an anchor study in the southern Benguela upwelling system: fecundity estimates of the dominant copepod, Calanoides carinatus. Prog Oceanogr 28:167-188

Båmstedt U, Nejstgaard JC, Solberg PT (1999) Utilisation of small-sized food algae by Calanus finmarchicus (Copepoda, Calanoida) and significance of feeding history. Sarsia 84:19-38

Båmstedt U, Gifford DJ, Irigoien X, Atkinson A, Roman M (2000) Feeding. In: Harris RP, Wiebe PH, Lenz J, Skjoldal HR, Huntley M (eds) ICES zooplankton methodology manual. Academic Press, London, p 297-380

Besiktepe S, Dam HG (2002) Coupling of ingestion and defecation as a function of diet in the calanoid copepod Acartia tonsa. Mar Ecol Prog Ser 229:151-164

Binet D, Suisse de Sainte Claire E (1975) Le copépode planctonique Calanoides carinatus. Répartition et cycle biologique au large de la Côte d'Ivoire. Cah ORSTOM Sér Océanogr 13:15-30

Calbet A, Saiz E, Alcaraz M (2002) Copepod egg production in the NW Mediterranean: effects of winter environmental conditions. Mar Ecol Prog Ser 237:173-184

Ceballos S, Álvarez-Marqués F (2006) Seasonal dynamics of reproductive parameters of the calanoid copepods Calanus helgolandicus and Calanoides carinatus in the Cantabrian Sea (SW Bay of Biscay). Prog Oceanogr (in press)

Ceballos S, Cabal JA, Álvarez-Marqués F (2004) Reproductive strategy of Calanoides carinatus and Calanus helgolandicus during a summer upwelling event off NW Spain. Mar Biol 145:739-750

Cushing DH (1989) A difference in structure between ecosystems in strongly stratified waters and those that are only weakly stratified. J Plankton Res 11:1-13

Dam HG, Peterson WT, Bellantoni DC (1994) Seasonal feeding and fecundity of the calanoid copepod Acartia tonsa in Long Island Sound: Is omnivory important to egg production? Hydrobiologia 292/293:191-199

Durbin EG, Runge JA, Campbell RG, Garrahan PR, Casas MC, Plourde S (1997) Late fall-early winter recruitment of Calanus finmarchicus on Georges Bank. Mar Ecol Prog Ser 151:103-114

Edler L, Hallfors G, Niemi A (1984) A preliminary check-list of the phytoplankton of the Baltic.Sea. Acta Bot Fenn 128: $1-26$ 
Fernández E, Bode A (1991) Seasonal patterns of primary production in the central Cantabrian Sea (Bay of Biscay). Sci Mar 55:629-636

Fernández E, Bode A (1994) Succession of phytoplankton assemblages in relation to the hydrography in the southern Bay of Biscay: a multivariate approach. Sci Mar 58: 191-205

Fernández E, Cabal J, Acuña JL, Bode A, García-Soto C (1993) Plankton distribution across a slope currentinduced front in the southern Bay of Biscay. J Plankton Res 15:619-641

González-Quirós R, Cabal J, Álvarez-Marqués F, Isla A (2003) Ichthyoplankton distribution and plankton production related to the shelf break front at the Avilés Canyon. ICES J Mar Sci 60:198-210

González-Quirós R, Pascual A, Gomis D, Anadón R (2004) Influence of mesoscale physical forcing on trophic pathways and fish larvae retention in the central Cantabrian Sea. Fish Oceanogr 13:351-364

Guisande C, Riveiro I, Maneiro I (2000) Comparisons among the amino acid composition of females, eggs and food to determine the relative importance of food quantity and food quality to copepod reproduction. Mar Ecol Prog Ser 202:135-142

Hansen B, Verity P, Falkenhaug $T$, Tande KS, Norrbin F (1994) On the trophic fate of Phaeocystis pouchetti (Harriot). V. Trophic relationship between Phaeocystis and zooplankton: an assessment of methods and size dependence. J Plankton Res 16:487-511

Harris RP, Malej A (1986) Diel patterns of ammonium excretion and grazing rhythms in Calanus helgolandicus in surface stratified waters. Mar Ecol Prog Ser 31:75-85

Hillebrand H, Dürselen CL, Kirschel D, Pollinger U, Zohay $T$ (1999) Biovolume calculation for pelagic and benthic microalgae. J Phycol 35:403-424

Hirche HJ (1983) Overwintering of Calanus finmarchicus and Calanus helgolandicus. Mar Ecol Prog Ser 11:281-290

Hirche HJ (1996) Diapause in the marine copepod, Calanus finmarchicus - a review. Ophelia 44:129-143

Huggett JA (2001) Reproductive response of the copepods Calanoides carinatus and Calanus agulhensis to varying periods of starvation in the southern Benguela upwelling region. J Plankton Res 23:1061-1071

Ianora A, Poulet SA, Miralto A (1995) A comparative study of the inhibitory effect of diatoms on the reproductive biology of the copepod Temora stylifera. Mar Biol 121:533-539

Ianora A, Miralto A, Poulet SA, Carotenuto Y and 8 others (2004) Aldehyde suppression of copepod recruitment in blooms of a ubiquitous planktonic diatom. Nature 429: 403-407

Ikeda T, Kamo Y, Ozaki K, Shimada A (2001) Metabolic rates of epipelagic marine copepods as a function of body mass and temperature. Mar Biol 139:587-596

Irigoien X, Harris RP, Head RN, Lindley JA, Harbour D (2000) Physiology and population structure of Calanus finmarchicus (Copepoda: Calanoida) during a Langrangian tracer release experiment in the North Atlantic. J Plankton Res 22:205-221

John HC, Mittelstaedt E, Schulz K (1998) The boundary circulation along the European continental slope as transport vehicle for two calanoid copepods in the Bay of Biscay. Oceanol Acta 21:307-318

Kiørboe T, Møhlenberg F, Hamburger K (1985) Bioenergetics of the planktonic copepod Acartia tonsa: relation between feeding, egg production and respiration, and composition of specific dynamic action. Mar Ecol Prog Ser 26:85-97
Laabir M, Poulet SA, Harris RP, Pond DW, Cueff A, Head RN, Ianora A (1998) Comparative study of the reproduction of Calanus helgolandicus in well-mixed and seasonally stratified coastal waters of the western English Channel. J Plankton Res 20:407-421

Lacoste A, Poulet SA, Cueff A, Kattner G, Ianora A, Laabir M (2001) New evidence of the copepod maternal food effects on reproduction. J Exp Mar Biol Ecol 259:85-107

Legendre L, Rassoulzadegan F (1996) Food-web mediated export of biogenic carbon in the oceans: hydrodynamic control. Mar Ecol Prog Ser 145:179-193

Levinsen H, Turner JT, Hansen BW (2000) On the trophic coupling between protists and copepods in arctic marine ecosystems. Mar Ecol Prog Ser 204:65-77

Mackas D, Bohner R (1976) Fluorescence analysis of zooplankton gut contents and an investigation of diel feeding patterns. J Exp Mar Biol Ecol 25:77-85

Mauchline J (1998) The biology of calanoid copepods. In: Blaxter JHS, Southward AJ, Tyler PA (eds) Advances in marine biology, 23. Academic Press, New York, p 710

Melle W, Skjoldal HR (1998) Reproduction and development of Calanus finmarchicus, C. glacialis and C. hyperboreus in the Barents Sea. Mar Ecol Prog Ser 169:211-228

Menden-Deuer S, Lessard EJ (2000) Carbon to volume relationship for dinoflagellates, diatoms, and other protist plankton. Limnol Oceanogr 45:569-579

Miralto A, Guglielmo L, Zagami G, Buttino I, Granata A, Ianora A (2003) Inhibition of population growth in the copepods Acartia clausi and Calanus helgolandicus during diatom blooms. Mar Ecol Prog Ser 254:253-268

Morales CE, Harris RP, Head RNH, Tranter PRG (1993) Copepod grazing in the oceanic northeast Atlantic during a 6 week drifting station: the contribution of size classes and vertical migrants. J Plankton Res 15:185-211

Niehoff B, Madsen SD, Hansen BW, Nielsen TG (2002) Reproductive cycles of three dominant Calanus species in Disko Bay, West Greenland. Mar Biol 140:567-576

Nielsen TG, Lokkegaard B, Richardson $K$, Pedersen FG, Hansen L (1993) Structure of plankton communities in the Dogger Bank area (North Sea) during a stratified situation. Mar Ecol Prog Ser 95:115-131

Omori M, Ikeda T (1984) Respiration and excretion. Methods in marine zooplankton ecology. J Wiley \& Sons, New York

Plourde S, Runge JA (1993) Reproduction of the planktonic copepod Calanus finmarchicus in the Lower St. Lawrence Estuary: relation to the cycle of phytoplankton production and evidence for a Calanus pump. Mar Ecol Prog Ser 102:217-227

Pohnert G, Lumineau O, Cueff A, Adolph S, Cordevant C, Lange M, Poulet SA (2002) Are volatile unsaturated aldehydes from diatoms the main line of chemical defence against copepods? Mar Ecol Prog Ser 245:33-45

Pond D, Harris R, Head R, Harbour D (1996) Environmental and nutritional factors determining seasonal variability in the fecundity and egg viability of Calanus helgolandicus in coastal waters off Plymouth, UK. Mar Ecol Prog Ser 143: 45-63

Poulet SA, Laabir M, Chaudron Y (1996) Characteristic features of zooplankton in the Bay of Biscay. Sci Mar 66: 79-95

Putt M, Stoecker DK (1989) An experimentally determined carbon: volume ratio for marine oligotrichous ciliates from estuarine and coastal waters. Limnol Oceanogr 34: $1097-1103$

Rey-Rassat C, Irigoien X, Harris R, Carlotti F (2002a) Energetic cost of gonad development in Calanus finmarchicus and C. helgolandicus. Mar Ecol Prog Ser 238:301-306 
Rey-Rassat C, Irigoien X, Harris R, Head R, Carlotti F (2002b) Egg production rates of Calanus helgolandicus females reared in the laboratory: variability due to present and past feeding conditions. Mar Ecol Prog Ser 238:139-151

Richardson K, Jónasdóttir SH, Hay S, Christoffersen A (1999) Calanus finmarchicus egg production and food availability in the Faroe-Shetland Channel and northern North Sea. Fish Oceanogr 8:153-162

Richardson AJ, Verheye HM, Rogers C, Arendse LM (2001) Egg production, somatic growth and productivity of copepods in the Benguela Current system and AngolaBenguela front. S Afr J Mar Sci 97:251-257

Runge JA (1988) Should we expect a relationship between primary production and fisheries? The role of copepod dynamics as a filter of trophic variability. Hydrobiologia 167/168:61-71

Runge JA, Roff JC (2000) The measurement of growth and reproductive rates. In: Harris RP, Wiebe $\mathrm{PH}$, Lenz J, Skjoldal HR, Huntley M (eds) ICES zooplankton methodology manual. Academic Press, London, p 401-444

Sherr EB, Sherr BF (1994) Bacterivory and herbivory: a key role of phagotrophic protists in pelagic food webs. Microb Ecol 28:223-235

Smith S (1995) The Arabian Sea: mesozooplankton response to seasonal climate in a tropical ocean. ICES J Mar Sci 52:427-438

Smith S (2001) Understanding the Arabian Sea: reflections on the 1994-1996 Arabian Sea Expedition. Deep-Sea Res II 48:1385-1402

Editorial responsibility: Otto Kinne (Editor-in-Chief), Oldendorf/Luhe, Germany
Tande KS (1982) Ecological investigations on the zooplankton community of Balsfjorden, Northern Norway: generation cycles, and variations in body weight and body content of carbon and nitrogen related to overwintering and reproduction in the copepod Calanus finmarchicus (Gunnerus). J Exp Mar Biol Ecol 62:129-142

Timonin AG, Arashkevich EG, Drits AV (1992) Zooplankton dynamics in the northern Benguela ecosystem, with special reference to the copepod Calanoides carinatus. S Afr J Mar Sci 12:545-560

Turner JT, Tester PA (1989) Zooplankton feeding ecology: non selective grazing by the copepods Acartia tonsa (Dana), Centropages velificatus (De Oliveira), and Eucalanus pileatus (Giesbrecht) in the plume of the Mississippi River. J Exp Mar Biol Ecol 126:21-43

Verheye HM, Hutchings L, Peterson WT (1991) Life history and population maintenance strategies of Calanoides carinatus (Copepoda: Calanoida) in the southern Benguela ecosystem. S Afr J Mar Sci 11:179-191

Williams R, Conway DVP (1982) Population growth and vertical distribution of Calanus helgolandicus in the Celtic Sea. Neth J Sea Res 16:185-194

Williams R, Conway DVP (1984) Vertical distribution, and seasonal and diurnal migration of Calanus helgolandicus in the Celtic Sea. Mar Biol 79:63-73

Williams R, Conway DVP (1988) Vertical distribution and seasonal numerical abundance of the calanidae in oceanic waters to the south-west of the British Isles. Hydrobiologia 167/168:259-266

Submitted: February 15, 2005; Accepted: October 25, 2005 Proofs received from author(s): June 1, 2006 